\title{
Cellular proliferation rate and insulin-like growth factor binding protein (IGFBP)-2 and IGFBP-3 and estradiol receptor alpha expression in the mammary gland of dairy heifers naturally infected with gastrointestinal nematodes during development
}

\author{
A. F. Perri, ${ }^{\star} †$ B. E. Dallard,† C. Baravalle,† N. Licoff, ${ }^{*}$ N. Formía,‡ H. H. Ortega,† D. Becú-Villalobos, ${ }^{*}$ \\ M. E. Mejia, ${ }^{*}$ and I. M. Lacau-Mengido*1 \\ *Laboratorio de Regulación Hipofisaria, Instituto de Biología y Medicina Experimental, Vuelta de Obligado 2490, 1428, \\ Ciudad Autónoma de Buenos Aires, Argentina \\ †Facultad de Ciencias Veterinarias, Universidad Nacional del Litoral, 3080, Esperanza, Santa Fe, Argentina \\ łEsc. Inchausti, Universidad Nacional de La Plata, 6667, 25 de mayo, Pcia. de Buenos Aires, Argentina
}

\begin{abstract}
Mammary ductal morphogenesis during prepuberty occurs mainly in response to insulin-like growth factor-1 (IGF-1) and estradiol stimulation. Dairy heifers infected with gastrointestinal nematodes have reduced IGF-1 levels, accompanied by reduced growth rate, delayed puberty onset, and lower parenchyma-stroma relationship in their mammary glands. Immunohistochemical studies were undertaken to determine variations in cell division rate, IGF-1 system components, and estradiol receptors (ESR) during peripubertal development in the mammary glands of antiparasitic-treated and untreated Holstein heifers naturally infected with gastrointestinal nematodes. Mammary biopsies were taken at 20, 30, 40 , and $70 \mathrm{wk}$ of age. Proliferating cell nuclear antigen immunolabeling, evident in nuclei, tended to be higher in the parenchyma of the glands from treated heifers than in those from untreated. Insulin-like growth factor binding proteins (IGFBP) type 2 and type 3 immunolabeling was cytoplasmic and was evident in stroma and parenchyma. The IGFBP2-labeled area was lower in treated than in untreated heifers. In the treated group, a maximal expression of this protein was seen at 40 wk of age, whereas in the untreated group the labeling remained constant. No differences were observed for IGFBP3 between treatment groups or during development. Immunolabeling for $\alpha$ ESR (ESR1) was evident in parenchymal nuclei and was higher in treated than in untreated heifers. In the treated group, ESR1 peaked at 30 wk of age and then decreased. These results demonstrate that the parasite burden in young heifers negatively influence mammary gland development, affecting
\end{abstract}

Received February 19, 2014.

Accepted May 4, 2014.

${ }^{1}$ Corresponding author: ilacau@ibyme.conicet.gov.ar cell division rate and parameters related to estradiol and IGF-1 signaling in the gland.

Key words: prepubertal mammary gland, proliferating cell nuclear antigen, insulin-like growth factor binding protein, estradiol receptor alpha

\section{INTRODUCTION}

Milk production is a function of the number of mammary epithelial cells and their secretory activity. The bulk of the mammary epithelium, which constitutes the parenchyma of the gland, grows allometrically (faster than the rest of the body) during the peripubertal period and pregnancy. It has been stated that future milk yield potential depends on the optimum development of the tissue that is established around the time of puberty (Akers et al., 2005). Mammary development during peripuberty consists of growth and branching of ducts of parenchymal cells, from the nipple to the inner of the gland, filling up the mesenchymal fat pad. This ductal morphogenesis occurs in response to specific hormones and growth factors that stimulate growth and differentiation in the different maturational stages of the gland (McNally and Martin, 2011). Both IGF-1 and estradiol are the main promoters of ductal growth during puberty and synergize in their action, whereas progesterone mainly acts during pregnancy, and also requires IGF-1 presence (Kleinberg and Barcellos-Hoff, 2011). This growth factor strongly stimulates parenchymal cell division during early mammary development and synergizes with estradiol for ductal growth and branching promotion (Hinck and Silberstein, 2005). Within the gland, paracrine interactions between stromal and parenchymal cells take place, which involve growth factors and their receptors, whose actions are finely tuned by external hormones (Forsyth, 1991; Akers et al., 2005; Kleinberg and Barcellos-Hoff, 2011). Particularly, the temporal expression of IGF-1, its re- 
ceptors, and binding proteins has been demonstrated to change within the gland according to physiological state (development, lactation, and involution of the gland) in a highly regulated manner (Plath-Gabler et al., 2001).

In animals fed on pastures, natural infections with gastrointestinal nematodes are common. Gastrointestinal parasitism is a major constraint to animal health, productivity, and profitability in grazing livestock production systems. In Argentine farms, replacement dairy heifers are mostly grown outdoors and allowed free grazing on pastures when they are as young as 60 $\mathrm{d}$ of age, therefore they are vulnerable to high infection threat. Dairy heifers with gastrointestinal nematodes have reduced growth rate, delayed age at puberty and at production onset, and increased culling rate during the following first lactation (Mejía et al., 1999; Mejía et al., 2009). Altered profiles of serum IGF-1, leptin, and luteinizing hormone pulsatile secretion were associated with the detrimental effect of the nematodes (Lacau-Mengido et al., 2000; Díaz-Torga et al., 2001). Particularly, IGF-1 levels during the whole prepubertal and pubertal period were significantly reduced in the parasitized when compared with antiparasitic-treated age-matched animals (Lacau-Mengido et al., 2000). The IGF-1 is a key factor for mammary gland development during the peripubertal period, and, consequently, a detrimental effect of parasites on parenchymal development was recently demonstrated (Perri et al., 2013). In the present work, to define the mechanisms involved in differential gland development, we investigated whether anthelmintic treatment in naturally infected dairy heifers during early development could modify the cellular division rate of mammary parenchymal and stromal cells as well as the expression pattern of modulators in the gland, such as IGF-1 system components and estradiol receptor $\alpha$ (ESR1).

\section{MATERIALS AND METHODS}

The experiment was conducted at the dairy farm of the Experimental School of Inchausti, 25 de Mayo, Province of Buenos Aires, Argentina ( $\left.35^{\circ} 36^{\prime} \mathrm{S}, 60^{\circ} 32^{\prime} \mathrm{W}\right)$. Forty-four female Holstein calves were randomly assigned to an untreated $(\mathbf{U})$ or to a treated group $(\mathbf{T})$ at birth. The $\mathrm{T}$ heifers received monthly, from birth to 18 mo of age, different anthelmintic drugs to minimize parasite burden avoiding drug resistance generation. The following drugs were used: ivermectin $(0.63 \mathrm{mg} /$ $\mathrm{kg})$, fenbendazol $(7.5 \mathrm{mg} / \mathrm{kg})$, and levamisol $(10 \mathrm{mg} /$ kg; Perri et al., 2013).

All the heifers were raised together with the reposition herd of the dairy farm, outdoors on infected pastures. At birth, calves were placed in individual cages, directly on the pastures, which were moved when the floor turned dirty or humid. They stayed in cages during the first 2 mo of life, and during this time they were fed $2 \mathrm{~L}$ of warm milk twice a day and had ad libitum access to balanced supplement. Then, they were included in the grazing herd and grazed on alfalfa and (or) ryegrass pastures, in a rotational grazing system (stocking density: 8 animals/ha), with ad libitum access to the supplement. At $160 \mathrm{~kg}$ of BW, the supplement was changed to corn ( $2 \mathrm{~kg} /$ animal per day) and the stocking density was reduced to 2 animals/ha.

At 20,30, 40, and $70 \mathrm{wk}$ of age, mammary biopsies were taken from 6 heifers in each group (Perri et al., 2013). Briefly, heifers were sedated with $1 \%$ acepromazine $(0.15 \mathrm{mg} / \mathrm{kg}$, Holliday Scott S.A., Buenos Aires, Argentina) and immobilized in a supine position. Udders were cleaned with soap and water, then rinsed and disinfected with iodinated solution. The biopsy was taken $2 \mathrm{~cm}$ away from the nipple in the rear right quarter, under local anesthesia ( $5 \mathrm{~mL}$ of lidocaine $2 \% \mathrm{sc}$ ). Each biopsy (at 20, 30, 40, and $70 \mathrm{wk}$ ) was obtained in a different place avoiding previous cicatrix. A Tru-Core I fully automatic biopsy gun provided with a Tru-Core 14 gauge $\times 20-\mathrm{cm}$ needle (Medical Device Technologies Inc., Gainesville, FL) was used. The needle directly pierced the skin and took a gland sample 3 -mm wide $\times$ 1 -cm long at approximately $2.5 \mathrm{~cm}$ of depth with minimal lesion. Mammary gland samples were immediately fixed in buffered $4 \%$ formaldehyde and transferred $24 \mathrm{~h}$ later to $70 \%$ ethanol until processed.

At the same moment, jugular blood and fecal samples were individually taken from all the heifers in the study for serum IGF-I determination by RIA and nematode egg counting [eggs per gram (EPG)] in feces. Blood samples were centrifuged and sera stored at $-20^{\circ} \mathrm{C}$ for IGF-1 determination. Fecal samples were maintained at $4^{\circ} \mathrm{C}$ until examination. Extra blood samples for progesterone determination by RIA were obtained weekly from 20 wk of age until the end of the experiment, to establish age of puberty onset. All the procedures were consistent with the Guide for the Care and Use of Agricultural Animals in Research and Teaching (FASS, 2010).

\section{Histological and Immunohistochemical Procedures}

Samples were fixed in buffered formaldehyde for 8 $\mathrm{h}$ at $4^{\circ} \mathrm{C}$, then rinsed abundantly with tap water and PBS ( $\mathrm{pH} 7.4 ; 0.01 M)$, subjected to dehydration in increasing concentrations of ethanol, washed in xylol, and embedded in paraffin. Serial sections, 5 - $\mu \mathrm{m}$ thick, were cut with a manual microtome and mounted on glass slides previously coated with 3-aminopropyltriethoxysilane (Sigma-Aldrich, St. Louis, MO). Slides 
were then deparaffinized and hydrated in graded ethanols. Primary antibodies for proliferating cell nuclear antigen (PCNA), ESR1, insulin-like growth factor binding protein types 2 (IGFBP2) and 3 (IGFBP3), their concentration, antigen retrieval pretreatments, and second antibodies for each case, are listed in Table 1. The endogenous peroxidase activity was inhibited with $1 \% \mathrm{H}_{2} \mathrm{O}_{2}$ in methanol and nonspecific binding was blocked with $10 \%$ normal goat serum. Each antibody was used in at least 5 sections per sample. Slides were incubated for $18 \mathrm{~h}$ at $4^{\circ} \mathrm{C}$ with primary antibodies, then rinsed 3 times, 5 min each, with PBS and incubated with the biotinylated second antibody for $30 \mathrm{~min}$ at $20^{\circ} \mathrm{C}$ (Table 1 ). The reactions were developed using a streptavidin-biotin peroxidase (BioGenex, San Ramon, CA) method and diaminobenzidine (Liquid DAB-Plus substrate kit, Zymed, San Francisco, CA) as a chromogen substrate (Dallard et al., 2007). Finally, slides were washed with distilled water, counterstained with Meyer's hematoxylin, dehydrated, and mounted with permanent mounting medium. For all the tested primary antibodies, unspecific controls were performed in adjacent sections replacing them by the respective mouse or rabbit nonimmune serum (Luque et al., 2011; Dallard et al., 2013).

\section{Image Analysis}

Images from every histological-stained section of all biopsies were obtained by means of a color video camera (CCD Moticam 2000, Mikron Instrument Inc., Carlsbad, CA) mounted on a optical microscope (Olympus CX31, Olympus Co., Tokyo, Japan) with a $40 \times$ objective. Images were digitalized and saved in TIFF format with a $1,200 \times 1,600$ pixel definition and 24 color bits. Each field represented a tissue area of $0.032 \mathrm{~mm}^{2}$ and each pixel $0.13 \mu \mathrm{m}$. Image-Pro Plus 3.0.1 1 (Media Cybernetics, Silver Spring, MA) was used for image analyses.

\section{Immunohistochemistry Quantification}

The area labeled by each antibody reaction (for PCNA, IGFBP2, IGFBP3, and ESR1) was quantified as a percentage of total explored area, using a segmentation color method previously described (Dallard et al., 2011, 2013). The darkest from the main color (brown) of the immunolabeled area was identified and assigned to "black" in the black-and-white mask generated by the software, definitively separating it from the rest of the colors in the picture. These values were verified and normalized, with the controls carried across various runs of immunohistochemistry, and the same region (verified by image comparison) was used for calibration (Ortega et al., 2009). The black percentage area was calculated for at least 50 images for each slide with parenchymal and stromal structures. An example of a mask generated for nuclear staining (PCNA) and one for cytoplasmic staining (IGFBP2) is shown in Figure 1 .

Proliferating nuclei, identified by anti-PCNA, were stained with different intensities (weak, moderate, and strong). The same pattern was evident for nuclei identified for the presence of ESR1. In both cases only the strong stained ones were assigned to the black mask, leaving weak and moderate stained nuclei in the white zone. For PCNA and ESR1 quantification, the parenchymal and stromal boundaries were delineated using the manual measurement tool in Image Pro-Plus software. Terminal ductal unities were identified and included along with myoepithelial cells in the parenchymal delimited zone. For PCNA, the immunohistochemical-stained areas (percent of black area) were calculated separately for parenchyma and stroma. For ESR1, the percentages of immunohistochemical-stained area were calculated relative to the area of parenchyma. In the case of binding proteins, IGFBP2 and IGFBP3, all the tissue area in the picture, without differentiation between parenchyma and stroma, was considered for the calculation of the percentage of immunostained area.

Table 1. List of primary and secondary antibodies used in the present experiment $(\mathrm{PCNA}=$ proliferating cell nuclear antigen, ESR $1=\alpha$ estradiol receptor, IGFBP = insulin-like growth factor binding protein)

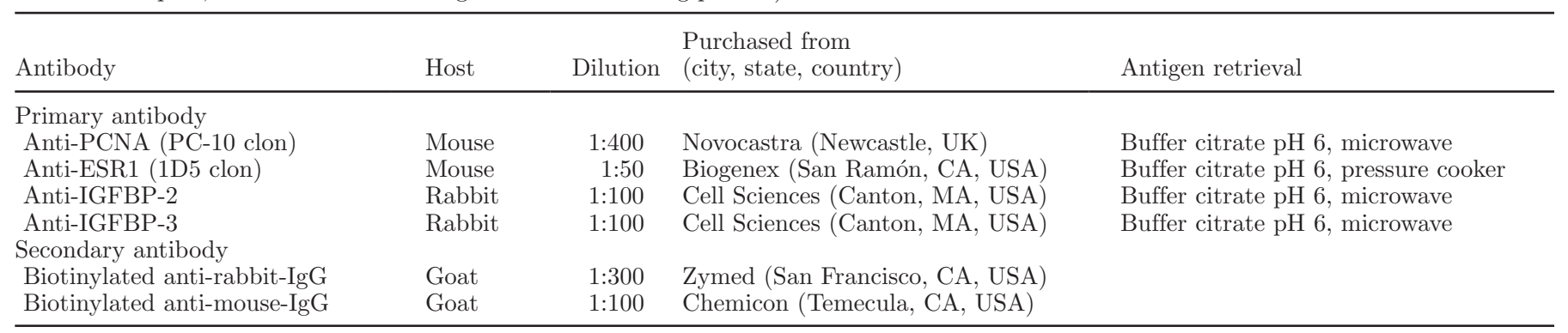



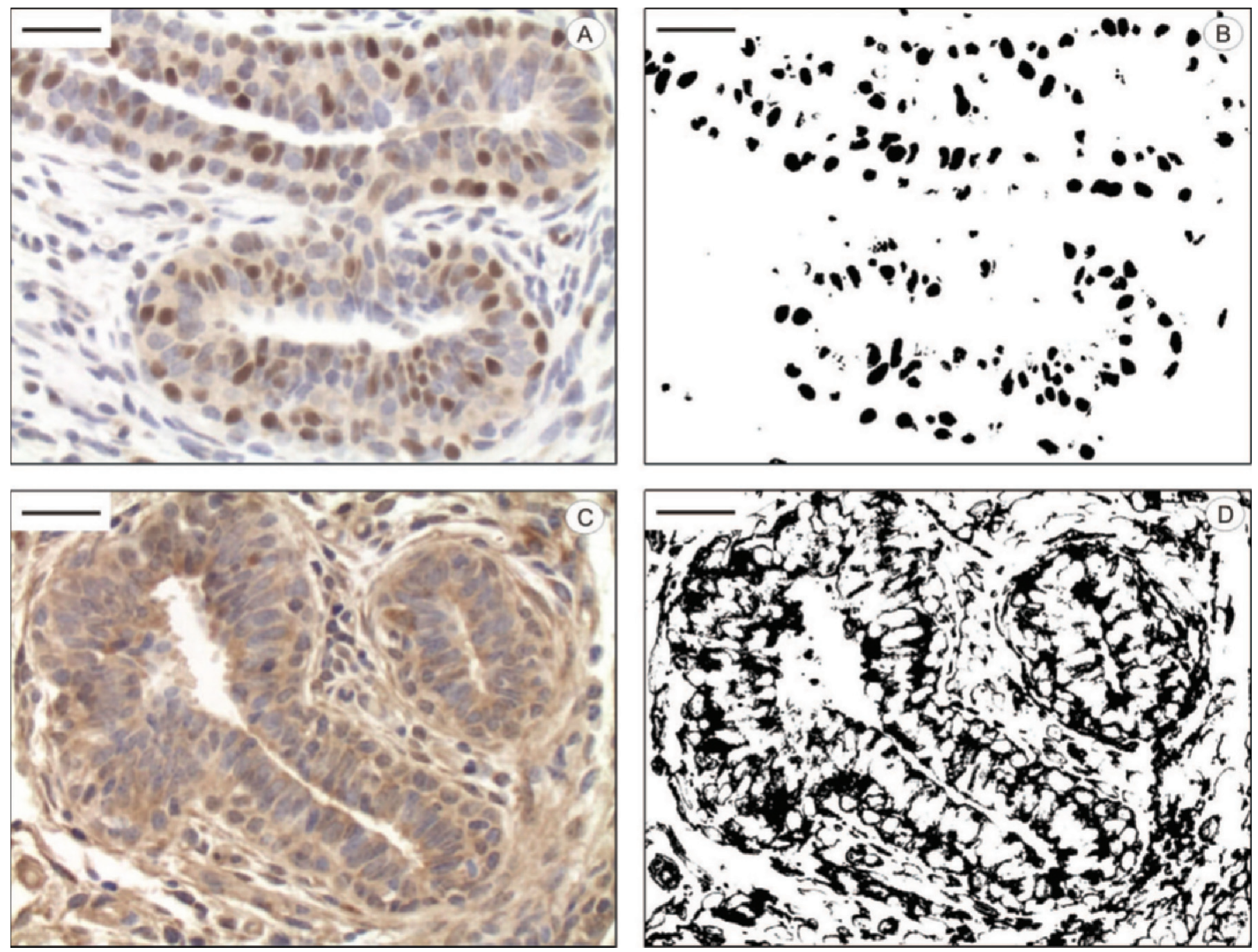

Figure 1. Representative images of nuclear labeling (proliferating cell nuclear antigen; A) and cytoplasmic labeling (insulin-like growth factor binding protein-2; C) in mammary tissue of antiparasitic-treated heifers. Panels B and D are the images of their respective segmentation analyses. Color version available in the online PDF.

\section{RIA}

The IGF-I RIA was performed after acid-ethanol extraction. The IGF-I antibody (UB2-495) of the National Institute of Diabetes and Digestive and Kidney Diseases (Bethesda, MD) was used (Becú-Villalobos et al., 2007). Intra-assay CV was $8 \%$, and the minimum detectable concentration was $2.5 \mathrm{ng}$. Progesterone was measured after double extraction with hexane. The RIA was performed using an antibody provided by G. D. Niswender (University of Colorado, Boulder), and labeled hormone \{progesterone $[1,2,6,73 \mathrm{H}(\mathrm{N})]\}$ was purchased from NEN-Radiochemicals (Perkin Elmer Inc., Waltham, MA). Assay sensitivity was $50 \mathrm{pg}$, and intra- and interassay CV were less than 8 and $12 \%$, respectively. Heifers were considered to be sexually ma- ture when progesterone concentration was $1 \mathrm{ng} / \mathrm{mL}$ or higher (Lacau-Mengido et al., 2000).

\section{Nematode Egg Counting}

Nematode eggs were counted in fresh fecal samples by the McMaster method adapted by the Instituto Nacional de Tecnología Agropecuaria, with a sensitivity of 10 eggs and expressed as EPG of sample (Mejía et al., 1999).

\section{Statistical Analysis}

Nonparametric tests were used to compare percentages of immunolabeled areas for PCNA, IGFBP2, IGFBP3, and ESR1 in the images because of lack of 
normality or homoscedasticity of the data series. The Friedman test was used to determine treatment and time effects and the Mann-Whitney test evaluated the effect of treatment within ages. Statistical significance was fixed at 0.05 , and a tendency was considered if $P$ was between 0.05 and 0.1. Treatment effect on EPG and IGF-1 values was analyzed by 2-way ANOVA for repeated measures (treatment $\times$ age); previous normalization of EPG variable was done using mathematical transformation $[\operatorname{arc}(\mathrm{EPG}+10)]$. Kaplan-Meier survival analysis was performed for pubertal comparison, setting puberty as the event and age as the variable. Posterior Log-rank test was used to compare both survival curves. Statistica 7 (StatSoft Inc. Tulsa, OK) and SPSS Statistics 19.0 (IBM, Armonk, NY) software was used.

\section{RESULTS}

Immunolabeling for PCNA and ESR1 was evident in stained nuclei, whereas immunolabeling for IGFBP2 and IGFBP3 was cytoplasmic. The PCNA-specific stained representative images for $1 \mathrm{~T}$ and $1 \mathrm{U}$ heifer are shown in Figure 2. An unspecific staining image is also shown. Nuclei labeled for PCNA were evident in both parenchyma and stroma. In terminal ductal unity structures, both epithelial and myoepithelial cells were highly labeled. Percent of immunolabeling in each group is graphically presented in Figure $3 \mathrm{~A}$ and $\mathrm{B}$ and tended to be higher in the parenchyma of glands from treated than in those from untreated heifers (Figure $3 \mathrm{~A} ; P=0.077)$. No differences were observed in the immunolabeling for PCNA in the stroma (Figure 3B; $P=0.32$ ).

Both IGFBP2- and IGFBP3-specific staining was present in stroma and parenchyma. Cytoplasm of epithelial and myoepithelial cells from the ducts was specifically labeled, as well as cytoplasm of fibroblasts and endothelial cells, and the stromal extracellular matrix (Figure 2). The IGFBP2-labeled area was lower in $\mathrm{T}$ than in $\mathrm{U}$ heifers $(P=0.04)$, and a tendency was observed for temporal variation in the $\mathrm{T}$ group $(P=$ 0.06 ), with a maximal expression of the protein at 40 wk of age. Immunolabeling for IGFBP2 during development remained constant in the untreated group (Figure $4 \mathrm{~A}$ ). No differences were observed for the IGFBP3 immunolabeled area between treatment groups or during development (Figure 4B).

Immunolabeling for ESR1 was also evident in parenchymal nuclei, mainly in medio-basal epithelium, at all studied ages. No staining was evident in nuclei from myoepithelial or stromal cells (Figure 2). Immunolabeled area in the parenchyma was higher in $\mathrm{T}$ than in $\mathrm{U}$ heifers $(P=0.021$, Figure 5$)$. An age effect was noted only for the $\mathrm{T}$ group $(P=0.042$ for $\mathrm{T}$, vs. $P=$
0.241 for $\mathrm{U})$. In the $\mathrm{T}$ group, the immunolabeled area increased at $30 \mathrm{wk}$ with respect to $20 \mathrm{wk}$ of age, and decreased at 40 and 70 wk. Nematode EPG counts in feces decreased with age $(P=0.027)$ and were higher in $\mathrm{U}$ than $\mathrm{T}$ heifers $(P=0.020)$. The IGF-1 concentrations increased with age $(P=0.003)$ and were higher in T than $\mathrm{U}$ heifers $(P=0.042$; Table 2$)$.

Differential sexual maturation between groups was evident by progesterone determination in serum. At 20 wk of age, all the heifers in both groups were sexually immature. At $30 \mathrm{wk}$, only 4 out of 22 and 2 out of 22 heifers were cycling in the $\mathrm{T}$ and $\mathrm{U}$ groups, respectively. At $40 \mathrm{wk}$ of age, all the heifers in the T group and 16 in the $\mathrm{U}$ were pubertal, and at $70 \mathrm{wk}$ of age all the heifers in both groups were already cycling. These data also indicate earlier puberty onset in $\mathrm{T}$ compared with $\mathrm{U}$ heifers when analyzed by survival curves and posterior Log-rank test $(P=0.018)$.

\section{DISCUSSION}

Mammary gland development during the peripubertal period can markedly affect future milk yield potential (Sejrsen and Purup, 1997). Thus, results reported herein are of importance for rearing dairy heifers on pastures, as they demonstrate that reducing parasite burden can effectively enhance cell division and alter signaling molecules related to estradiol and IGF-1 action in the developmental mammary gland. Because the future milk yield potential of ruminants will depend on optimum development of the tissue foundation that is established around the time of puberty (Akers et al., 2000), the present results enhance the importance of parasite control during development.

Antiparasitic-treated heifers had lower EPG levels and higher IGF-1 levels than untreated ones, as expected. Differences observed in EPG and IGF-1 between groups were sufficient to delay growth and puberty (Perri et al., 2013), although antiparasitic treatment did not totally suppress parasite oviposition because of drug resistance (Mejía et al., 1999, 2003). Differences in IGF-1 and sexual development encountered (Perri et al., 2013) suggested that differential mammary developmental features might occur.

The tendency for higher PCNA labeling in mammary parenchyma observed in the present study in the treated heifers compared with the untreated ones indicates a tendency for a higher rate of cell division. This is in accordance with the increased proportion of parenchymal area recently observed, which was related to lower parasite burden and a better nutritional state (Perri et al., 2013).

Both gastrointestinal parasite presence and undernutrition lower IGF-1 serum concentrations (Lacau- 
Negative controls

ESR1

IGFBP2

IGFBP3
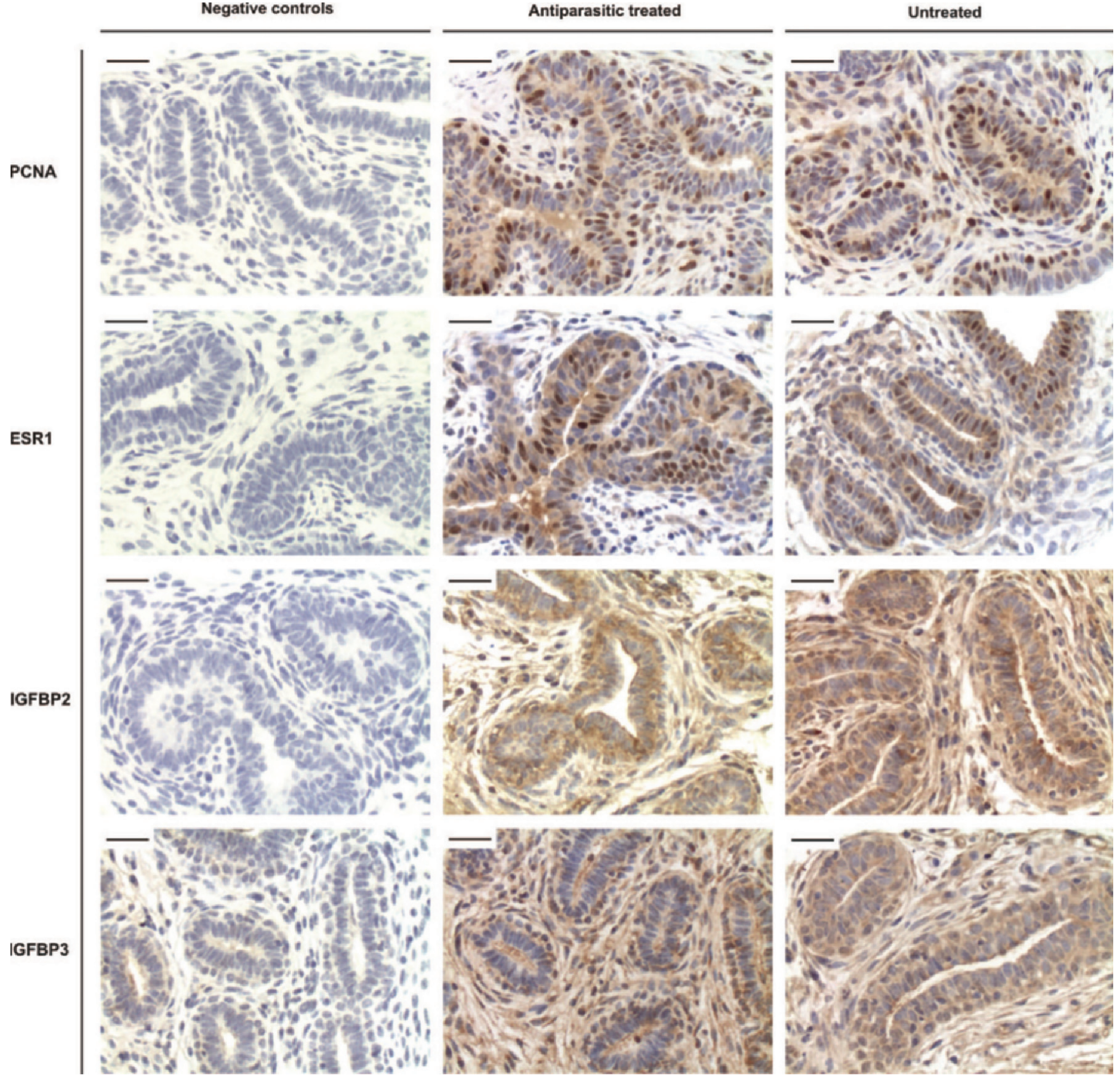

Figure 2. Representative images of proliferating cell nuclear antigen (PCNA), $\alpha$ estradiol receptors (ESR1), and insulin-like growth factor binding protein type 2 and 3 (IGFBP2 and IGFBP3) immunostaining in mammary tissue of antiparasitic-treated and untreated control heifers at 30 (ESR1) and $40 \mathrm{wk}$ (PCNA, IGFBP2, and IGFBP3) of age. Negative controls (replacement of primary antibodies with mouse or rabbit nonimmune serum) for immunostaining are shown in the left panels. Magnification is the same for all panels $(400 \times)$ and is indicated by $25-\mu m$ bars. Color version available in the online PDF.

Mengido et al., 2000; Odiere et al., 2010). Other cases of parasite infections, such as ticks, also showed systemic IGF-1decrease, which was more marked in the case of low nutritional levels (Tolleson et al., 2010), and which has been related with a decrease in hepatic growth hormone receptor expression (Tolleson et al., 2012). Improved weight gain and earlier puberty onset was also related to higher IGF-1 levels achieved by antiparasitic treatment in concordance with the present results (Perri et al., 2013). No other studies on parasite 

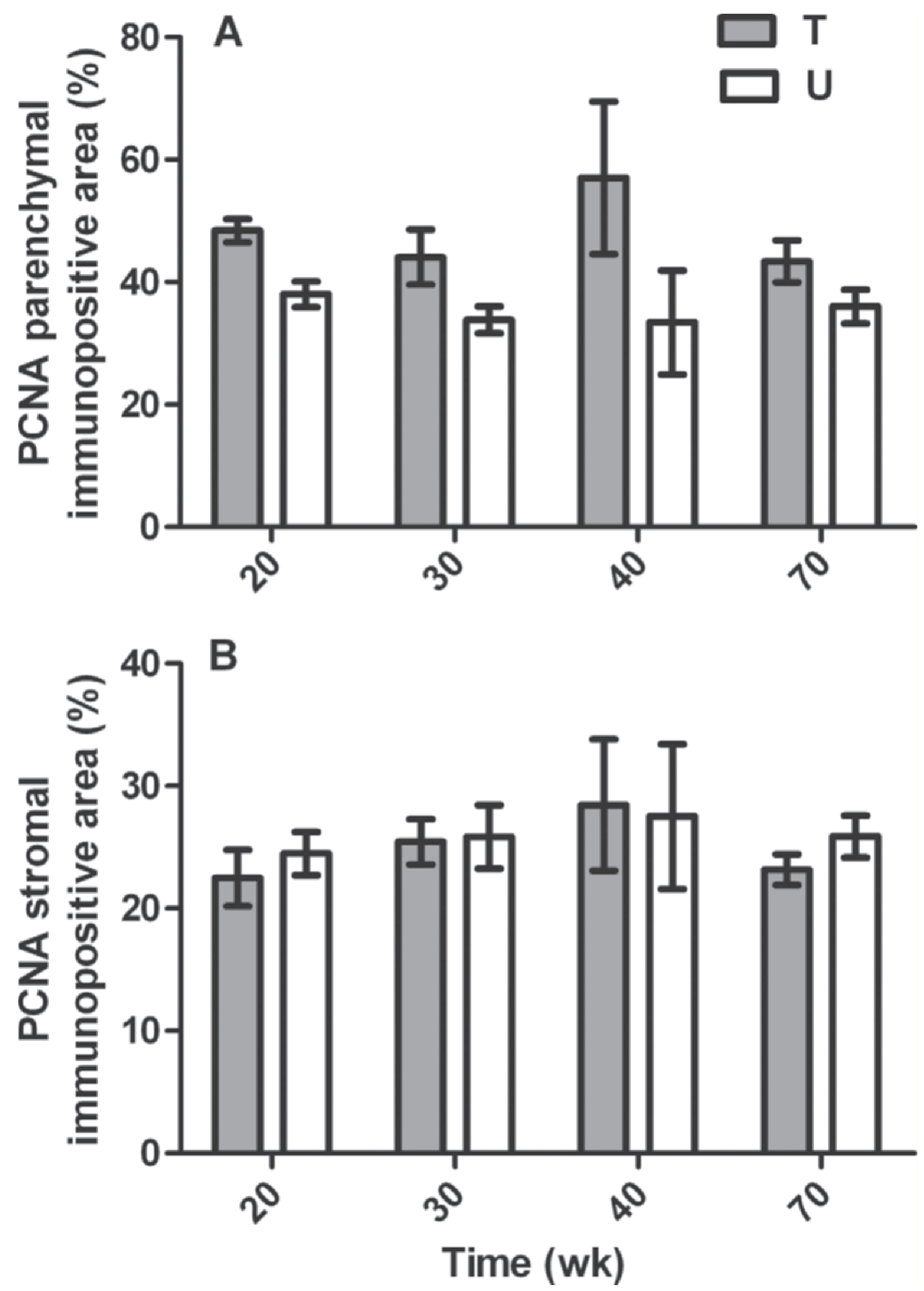

Figure 3. Percent of immunostaining for proliferating cell nuclear antigen (PCNA), in the mammary parenchyma (A) and stroma (B) of antiparasitic-treated and untreated heifers at 20,30,40, and 70 wk of age. Statistical results of the Friedman test were $P=0.08$ and $P=0.32$ for treatment differences in parenchymal and stromal analysis, respectively. For age differences $P>0.1$ in every case. $\mathrm{T}=$ treated (gray bars); $\mathrm{U}=$ untreated (white bars). Lines at the top of the bars represent $\pm 1 \mathrm{SE}$. 

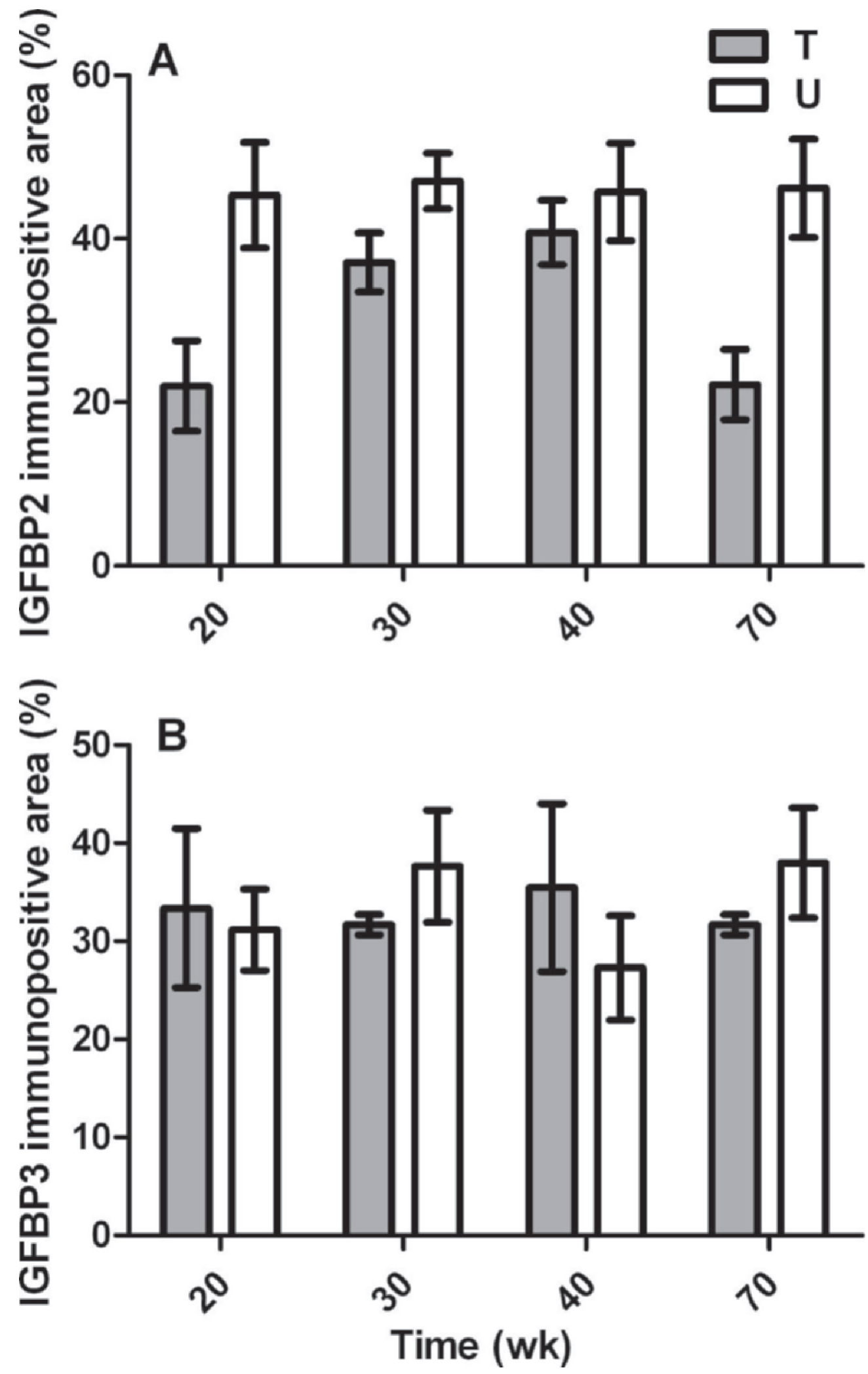

Figure 4. Percent of immunostaining for insulin-like growth factor binding protein type 2 (IGFBP2; A, $P=0.04$ for treatment effect, $P=$ 0.06 for age effect in treated heifers, and $P=0.98$ for age effect in untreated heifers) and for insulin-like growth factor binding protein type 3 (IGFBP3; B; $P>0.1$ for all treatment and time effects) in mammary glands of antiparasitic-treated and untreated heifers at 20, 30, 40, and 70 wk of age. $\mathrm{T}=$ treated (gray bars); $\mathrm{U}=$ untreated (white bars). Lines at the top of the bars represent $\pm 1 \mathrm{SE}$. 
Table 2. Amount of nematode eggs per gram of feces (EPG; mean \pm SE) and serum concentration of insulinlike growth factor-1 (IGF-1; mean \pm SE) at biopsy times $(20,30,40$, and 70 wk of age) in untreated (U) and anthelmintic treated $(\mathrm{T})$ heifers

\begin{tabular}{lcccc}
\hline & \multicolumn{4}{c}{ Age (wk) } \\
\cline { 2 - 5 } Item & 20 & 30 & 40 & 70 \\
\hline EPG & & & & \\
U & $188 \pm 65$ & $126 \pm 45$ & $119 \pm 30$ & $110 \pm 40$ \\
T & $81 \pm 27^{*}$ & $45 \pm 20^{*}$ & $53 \pm 13^{*}$ & $30 \pm 12^{*}$ \\
IGF-1 $(\mathrm{ng} / \mathrm{mL})$ & & & & \\
$\mathrm{U}$ & $9.2 \pm 1.1$ & $10.0 \pm 1.1$ & $16.6 \pm 1.0$ & $21.0 \pm 3.6$ \\
$\mathrm{~T}$ & $12.7 \pm 1.2^{*}$ & $13.2 \pm 1.7^{*}$ & $20.7 \pm 1.8^{*}$ & $22.7 \pm 1.8$ \\
\hline
\end{tabular}

$* P<0.05$ respective to the untreated age-matched group.

(or antiparasitic treatment) effect on the mammary gland have been reported, but, as the pathogenesis of gastrointestinal nematode includes inappetence and increased loss of proteins into the gastrointestinal tract driving to an undernutritional status (Symons, 1985; Holmes, 1987; Arneberg et al., 1996), a correlation with undernutritional situations can also be made. To this regard, undernutrition in prepubertal sows has been shown to reduce parenchymal proportion in their mammary glands (Farmer et al., 2004). In heifers, however, results are controversial. For one, it was demonstrated that restricting protein in the diet of heifers fed for rapid growth rate impairs parenchymal mammary development (Whitlock et al., 2002) and that feeding high-energy and -protein diets during early development increased parenchymal mass and parenchymal DNA and RNA without increasing deposition of fat (Brown et al., 2005). Conversely, when heifers were fed to reach ADG equal or superior to $1 \mathrm{~kg}$ with very highenergy diets, a reduction in parenchymal proportion, reduced epithelial cell division in the mammary gland, and increased mammary fat deposition were observed (Capuco et al., 1995; Dobos et al., 2000; Davis-Rincker et al., 2008). This resulted in reduced parenchymal-

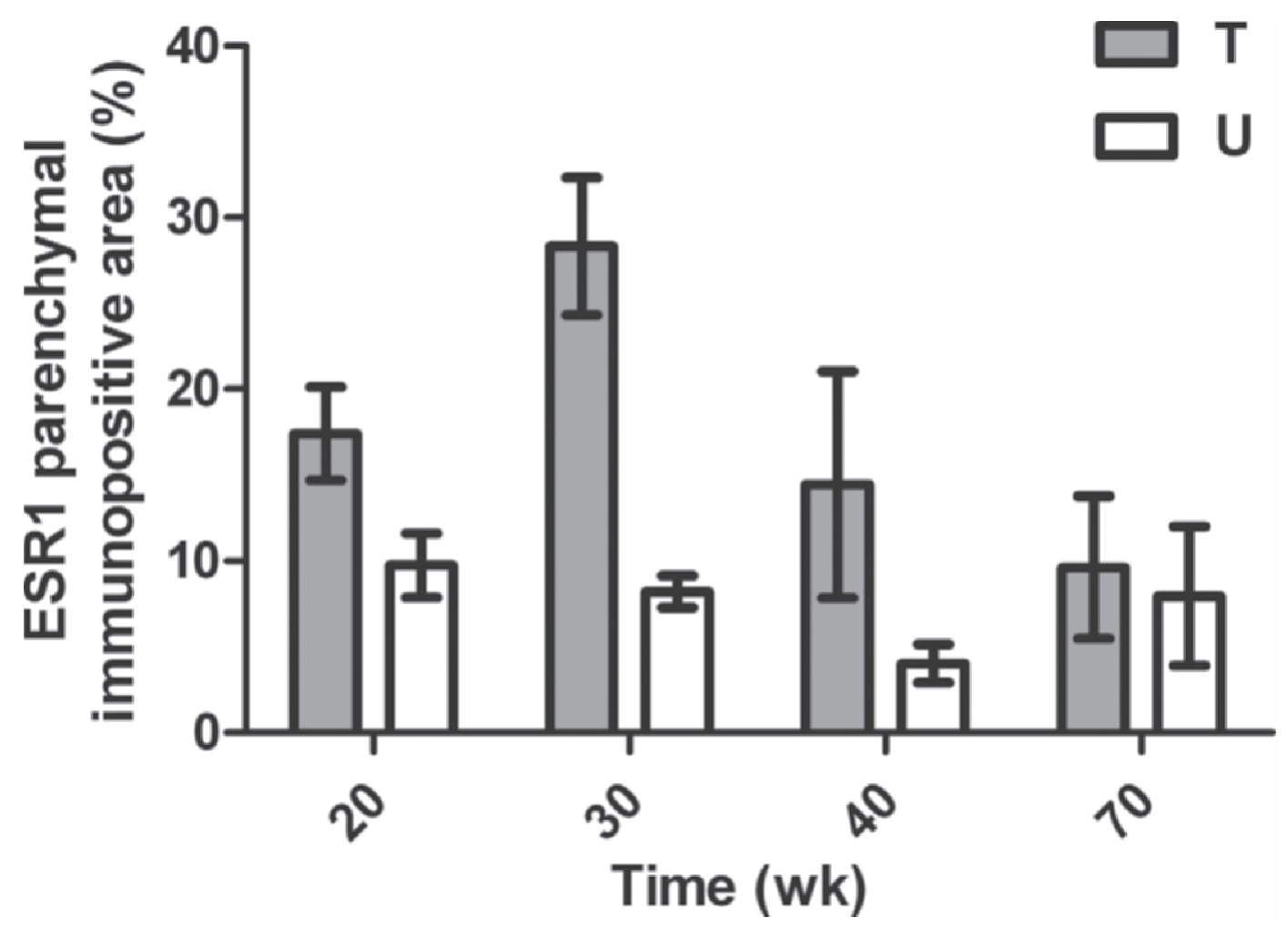

Figure 5. Percent of immunostaining for $\alpha$ estradiol receptors (ESR1) in the mammary parenchyma of antiparasitic-treated and untreated heifers at $20,30,40$, and $70 \mathrm{wk}$ of age $(P=0.02$ for treatment effect, $P=0.04$ for age effect in treated heifers, and $P=0.42$ for age in untreated heifers). $\mathrm{T}=$ treated (gray bars); $\mathrm{U}=$ untreated (white bars). Lines at the top of the bars represent $\pm 1 \mathrm{SE}$. 
stromal mass and suggested a deleterious effect of prepubertal rapid weight gain (with a high rate of fat deposition) on prepubertal mammogenesis. Finally, in another case, the parenchymal accretion rate was unaffected by nutritional levels (Meyer et al., 2006a), and it was stated that the composition of lipids and proteins of the mammary fat pad depends on the diet, but the composition of the parenchyma does not (Meyer et al., 2006b). In the present study, the heifers had a moderate daily weight gain (about $0.650 \mathrm{~kg} / \mathrm{d}$, data not shown). At this rate of gain, a high parasite burden resulted in decreased IGF-1 levels and decreased parenchyma development. Therefore, we suggest that the effect of decreased IGF-1 levels (produced either by parasitism or by undernutrition) can be seen histologically on mammary development when energy intake is moderate.

The IGF-1 can bind with high affinity to IGF binding proteins (IGFBP1 to 6), which increase its half-life and regulate its bioavailability (Akers et al., 2005). These proteins are present in blood and tissues and are differentially regulated according to tissue, age, sex, and physiological state (Holly and Perks, 2012; Reindl and Sheridan, 2012). Their expression has been detected in the growing and mature bovine mammary gland (Plath-Gabler et al., 2001). Both IGFBP2 and IGFBP3 exert a role in the regulation of tissue development by IGF-1, including mammary parenchyma (Akers et al., 2005). Expression of both proteins was evident in the parenchyma and the stroma of the gland, as reported by others (Weber et al., 2000).

Increase of IGFBP2 has been shown to delay development in fetuses and reduce BW and skeleton growth (Tapanainen et al., 1994; Hoeflich, 2008), and also impair IGF-1 promotion of mammary gland development (Hadsell et al., 1996; Wolf et al., 1997). Coincidentally, in our study, high immunolabeling of IGFBP2 in untreated heifers was related with lower development of the parenchyma (Perri et al., 2013) and also a lower rate of cell division. Differential expression of IGFBP2 observed between treated and untreated heifers may be due to the alteration of nutritional situation or pathological condition, as serum IGFBP2 has been also shown to be increased in fasting and in a variety of diseases (Wolf et al., 2000). Nevertheless, a direct effect of decreased IGF-1 on the binding protein synthesis cannot be ruled out.

In the case of modulatory functions of IGFBP3, stimulatory and inhibitory effects on IGF-1 action have been described, depending on the experimental design (Berry et al., 2001). This protein has also been involved in functions not directly related to IGF-1 modulation, such as interaction with lactoferrin to favor apoptosis during mammary development and postlactation invo- lution (Blum and Baumrucker, 2002). No changes were detected between groups in mammary immunolabeling for IGFBP3, even though this protein is also synthesized within the gland (Weber et al., 2000), indicating that it does not have a major participation in parenchyma development induced by IGF-1.

Ovarian steroids increase dramatically during prepuberty when allometric mammary growth begins. Ductal elongation is stimulated by estradiol acting on estrogen receptors (Fendrick et al., 1998). Two isoforms of these receptors have been described-ESR1 and $\beta$-estradiol receptor - and both are present in the bovine mammary gland, the $\alpha$ isoform being predominant (Connor et al., 2005; Meyer et al., 2007). In mice it has been demonstrated that stromal ESR1 are essential for ductal growth (Cunha et al., 1997) and are already present at birth, although they are not responsive to estradiol at this time. During the period immediately previous to puberty, their number increases dramatically and the gland becomes sensitive to the hormone (Haslam, 1989; Imagawa et al., 2002). Both stromal and epithelial ESR1, as well as progesterone receptors, are needed in mice for normal development of the mammary gland (Mueller et al., 2002). However, immunohistochemical studies in the bovine mammary gland and real-time PCR mRNA expression from laser microdissected cells have shown that ESR1 expression is restricted to parenchymal tissue, strictly confined to epithelial cells that cover the ducts, and is very uncommon in stromal cells (Capuco et al., 2002; Berry et al., 2003). About one-third of epithelial cells express ESR1, and this expression is mainly associated with cells embedded in the epithelium and in contact with the basal membrane (Capuco and Ellis, 2005). In accordance with these reports, in the present study ESR1 expression was detected in nuclei from medial and basal cells of terminal ductal units.

In the bovine mammary gland, ESR1 expression has been shown to increase until $100 \mathrm{~kg}$ of BW, paralleling IGF-1 circulating levels, and then decrease when the animal reaches puberty and IGF-1 levels stabilize (Connor et al., 2005; Meyer et al., 2007). In the present work, treated heifers had higher ESR1 immunolabeling than untreated ones during development. This may be related to higher systemic IGF-1 levels and probably higher bioavailable IGF-1 within the gland (probably related to the lower IGFBP2 found), which may upregulate receptor expression (Imagawa et al., 1990; Woodward et al., 1998).

In the treated group, the increase in ESR1 immunolabeling observed at $30 \mathrm{wk}$ of age, corresponded to an average BW of $135 \mathrm{~kg}$ and a stage in which only $20 \%$ of cycling heifers were found. Between the samplings at 30 and $40 \mathrm{wk}$, all the heifers in this group reached pu- 
berty, and immunolabeling for the receptor decreased, as reported by others (Connor et al., 2005; Meyer et al., 2007). In the untreated group, however, no temporal variation in immunolabeling of ESR1 was evidenced in the chosen biopsy times. Thus, whether the increase in immunolabeling was delayed or was less marked, due to lower IGF-1 levels, cannot be ascertained.

These results demonstrate a temporal variation in IGF-1- and estradiol-related components in the bovine mammary gland during development and add new evidence about the importance of parasite control in dairy herds for correct mammary development. Most previous studies have been performed on beef herds, but increasing evidence of parasite effects on dairy cattle is now available (Nødtvedt et al., 2002; Sithole et al., 2005; Charlier et al., 2007; Perri et al., 2011). As epithelial cell number is crucial for mammary performance in adulthood, and it is thought to be dependent on peripubertal mammogenesis (Tucker, 1987; Sejrsen et al., 2000), the fact that parasite presence during puberty altered mammary developmental features may indicate that future productive capacity will be affected.

\section{ACKNOWLEDGMENTS}

This work was supported by Agencia Nacional de Promoción Científica y Tecnológica (ANPCYT, Ciudad Autónoma de Buenos Aires, Argentina) and Consejo Nacional de Investigaciones Científicas y Técnicas (CONICET, Ciudad Autónoma de Buenos Aires, Argentina).

\section{REFERENCES}

Akers, R. M., S. E. Ellis, and S. D. Berry. 2005. Ovarian and IGFI axis control of mammary development in prepubertal heifers. Domest. Anim. Endocrinol. 29:259-267.

Akers, R. M., T. B. McFadden, S. Purup, M. Vestergaard, K. Sejrsen, and A. V. Capuco. 2000. Local IGF-I axis in peripubertal ruminant mammary development. J. Mammary Gland Biol. Neoplasia 5:43-51.

Arneberg, P., I. Folstad, and A. J. Karter. 1996. Gastrointestinal nematodes depress food intake in naturally infected reindeer. Parasitology 112:213-219.

Becú-Villalobos, D., I. Garcia-Tornadu, G. Shroeder, E. E. Salado, G. Gagliostro, C. Delavaud, Y. Chilliard, and I. M. Lacau-Mengido. 2007. Effect of fat supplementation on leptin, insulin-like growth factor I, growth hormone, and insulin in cattle. Can. J. Vet. Res. $71: 218-225$.

Berry, S. D., P. M. Jobst, S. E. Ellis, R. D. Howard, A. V. Capuco, and R. M. Akers. 2003. Mammary epithelial proliferation and estrogen receptor alpha expression in prepubertal heifers: Effects of ovariectomy and growth hormone. J. Dairy Sci. 86:2098-2105.

Berry, S. D., T. B. McFadden, R. E. Pearson, and R. M. Akers. 2001. A local increase in the mammary IGF-1: IGFBP-3 ratio mediates the mammogenic effects of estrogen and growth hormone. Domest. Anim. Endocrinol. 21:39-53.

Blum, J. W., and C. R. Baumrucker. 2002. Colostral and milk insulinlike growth factors and related substances: Mammary gland and neonatal (intestinal and systemic) targets. Domest. Anim. Endocrinol. 23:101-110.
Brown, E. G., M. J. VandeHaar, K. M. Daniels, J. S. Liesman, L. T. Chapin. J. W. Forrest, R. M. Akers, R. E. Pearson, and M. S. Nielsen. 2005. Effect of increasing energy and protein intake on mammary development in heifer calves. J. Dairy Sci. 88:595-603.

Capuco, A. V., and S. Ellis. 2005. Bovine mammary progenitor cells: Current concepts and future directions. J. Mammary Gland Biol. Neoplasia 10:5-15.

Capuco, A. V., S. Ellis, D. L. Wood, R. M. Akers, and W. Garrett. 2002. Postnatal mammary ductal growth: Three-dimensional imaging of cell proliferation, effects of estrogen treatment, and expression of steroid receptors in prepubertal calves. Tissue Cell $34: 143-154$.

Capuco, A. V., J. J. Smith, D. R. Waldo, and C. E. Rexroad Jr. 1995. Influence of prepubertal dietary regimen on mammary growth of Holstein heifers. J. Dairy Sci. 78:2709-2725.

Charlier, J., L. Duchateau, E. Claerebout, and J. Vercruysse. 2007. Predicting milk-production responses after an autumn treatment of pastured dairy herds with eprinomectin. Vet. Parasitol. 143:322-328.

Connor, E. E., D. L. Wood, T. S. Sonstegard, A. F. da Mota, G. L. Bennett, J. L. Williams, and A. V. Capuco. 2005. Chromosomal mapping and quantitative analysis of estrogen-related receptor alpha-1, estrogen receptors alpha and beta and progesterone receptor in the bovine mammary gland. J. Endocrinol. 185:593-603.

Cunha, G. R., P. Young, Y. K. Hom, P. S. Cooke, J. A. Taylor, and D. B. Lubahn. 1997. Elucidation of a role for stromal steroid hormone receptors in mammary gland growth and development using tissue recombinants. J. Mammary Gland Biol. Neoplasia 2:393-402.

Dallard, B. E., C. Baravalle, C. Andreotti, H. H. Ortega, V. Neder, and L. F. Calvinho. 2011. Intramammary inoculation of Panax ginseng extract in cows at drying off enhances early mammary involution. J. Dairy Res. 78:63-71.

Dallard, B. E., S. A. Pujato, C. Baravalle, E. A. Pereyra, F. Rey, M. S. Renna, and L. F. Calvinho. 2013. Intramammary infusion of Panax ginseng extract in the bovine mammary gland at cessation of milking modifies components of the insulin-like growth factor system during involution. Res. Vet. Sci. 94:462-470.

Dallard, B. E., V. Ruffino, S. Heffel, and L. F. Calvinho. 2007. Effect of a biological response modifier on expression of growth factors and cellular proliferation at drying off. J. Dairy Sci. 90:2229-2240.

Davis Rincker, L. E., M. S. Weber Nielsen, L. T. Chapin, J. S. Liesman, K. M. Daniels, R. M. Akers, and M. J. VandeHaar. 2008. Effects of feeding prepubertal heifers a high-energy diet for three, six, or twelve weeks on mammary growth and composition. J. Dairy Sci. 91:1926-1935.

Díaz-Torga, G. S., M. E. Mejía, A. González-Iglesias, N. Formía, D. Becú-Villalobos, and I. M. Lacau-Mengido. 2001. Metabolic cues for puberty onset in free grazing Holstein heifers naturally infected with nematodes. Theriogenology 56:111-122.

Dobos, R. C., K. S. Nandra, K. Riley, W. J. Fulkerson, I. J. Lean, and R. C. Kellaway. 2000. The effect of dietary protein level during the pre-pubertal period of growth on mammary gland development and subsequent milk production in Friesian heifers. Livest. Prod. Sci. $63: 235-243$.

Farmer, C., D. Petitclerc, M. T. Sorensen, M. Vignola, and J. Y. Dourmad. 2004. Impacts of dietary protein level and feed restriction during prepuberty on mammogenesis in gilts. J. Anim. Sci. 82:2343-2351.

FASS. 2010. Guide for the Care and Use of Agricultural Animals in Research and Teaching. 3rd ed. Federation of Animal Science Societies, Champaign, IL.

Fendrick, J. L., A. M. Raafat, and S. Z. Haslam. 1998. Mammary gland growth and development from the postnatal period to postmenopause: Ovarian steroid receptor ontogeny and regulation in the mouse. J. Mammary Gland Biol. Neoplasia 3:7-22.

Forsyth, I. A. 1991. The mammary gland. Baillieres Clin. Endocrinol. Metab. 5:809-832.

Hadsell, D. L., N. M. Greenberg, J. M. Fligger, C. R. Baumrucker, and J. M. Rosen. 1996. Targeted expression of des(1-3) human insulinlike growth factor I in transgenic mice influences mammary gland 
development and IGF-binding protein expression. Endocrinology 137:321-330

Haslam, S. Z. 1989. The ontogeny of mouse mammary gland responsiveness to ovarian steroid hormones. Endocrinology 125:27662772 .

Hinck, L., and G. B. Silberstein. 2005. Key stages in mammary gland development: The mammary end bud as a motile organ. Breast Cancer Res. 7:245-251.

Hoeflich, A. 2008. Contrasting bone effects of temporary versus permanent IGFBP administration in rodents. Growth Horm. IGF Res. 18:181-187.

Holly, J. M., and C. M. Perks. 2012. Insulin-like growth factor physiology: what we have learned from human studies. Endocrinol. Metab. Clin. North Am. 41:249-263.

Holmes, P. H. 1987. Pathophysiology of nematode infections. Int. J. Parasitol. 17:443-451.

Imagawa, W., G. K. Bandyopadhyay, and S. Nandi. 1990. Regulation of mammary epithelial cell growth in mice and rats. Endocr. Rev. 11:494-523.

Imagawa, W., V. K. Pedchenko, J. Helber, and H. Zhang. 2002. Hormone/growth factor interactions mediating epithelial/stromal communication in mammary gland development and carcinogenesis. J. Steroid Biochem. Mol. Biol. 80:213-230.

Kleinberg, D. L., and M. H. Barcellos-Hoff. 2011. The pivotal role of insulin-like growth factor I in normal mammary development. Endocrinol. Metab. Clin. North Am. 40:461-471.

Lacau-Mengido, I. M., M. E. Mejía, G. S. Díaz-Torga, A. GonzálezIglesias, N. Formía, C. Libertun, and D. Becú-Villalobos. 2000. Endocrine studies in ivermectin-treated heifers from birth to puberty. J. Anim. Sci. 78:817-824

Luque, G. M., M. I. Perez-Millan, A. M. Ornstein, C. Cristina, and D. Becu-Villalobos. 2011. Inhibitory effects of antivascular endothelial growth factor strategies in experimental dopamine-resistant prolactinomas. J. Pharmacol. Exp. Ther. 337:766-774.

McNally, S., and F. Martin. 2011. Molecular regulators of pubertal mammary gland development. Ann. Med. 43:212-234.

Mejía, M. E., B. M. Fernández-Igartúa, E. E. Schmidt, and J. Cabaret. 2003. Multispecies and multiple anthelmintic resistance on cattle nematodes in a farm in Argentina: The beginning of high resistance? Vet. Res. 34:461-467.

Mejía, M., A. González-Iglesias, G. S. Díaz-Torga, P. Villafañe, N. Formía, C. Libertun, D. Becú-Villalobos, and I. M. Lacau-Mengido. 1999. Effects of continuous ivermectin treatment from birth to puberty on growth and reproduction in dairy heifers. J. Anim. Sci. 77:1329-1334.

Mejía, M. E., A. F. Perri, M. M. Miglierina, N. Formia, D. BecuVillalobos, and I. M. Lacau-Mengido. 2009. Effect of anthelmintics on reproductive performance and first-lactation culling rate in Holstein heifers. Vet. Rec. 165:743-746.

Meyer, M. J., A. V. Capuco, D. A. Ross, L. M. Lintault, and M. E. Van Amburgh. 2006a. Developmental and nutritional regulation of the prepubertal bovine mammary gland: II. Epithelial cell proliferation, parenchymal accretion rate, and allometric growth. J. Dairy Sci. 89:4298-4304.

Meyer, M. J., A. V. Capuco, D. A. Ross, L. M. Lintault, and M. E. Van Amburgh. 2006b. Developmental and nutritional regulation of the prepubertal heifer mammary gland: I. Parenchyma and fat pad mass and composition. J. Dairy Sci. 89:4289-4297.

Meyer, M. J., R. P. Rhoads, A. V. Capuco, E. E. Connor, A. Hummel, Y. R. Boisclair, and M. E. Van Amburgh. 2007. Ontogenic and nutritional regulation of steroid receptor and IGF-I transcript abundance in the prepubertal heifer mammary gland. J. Endocrinol. 195:59-66.

Mueller, S. O., J. A. Clark, P. H. Myers, and K. S. Korach. 2002. Mammary gland development in adult mice requires epithelial and stromal estrogen receptor alpha. Endocrinology 143:2357-2365.

Nødtvedt, A., I. Dohoo, J. Sanchez, G. Conboy, L. DesCoteaux, and G. Keefe. 2002. Increase in milk yield following eprinomectin treatment at calving in pastured dairy cattle. Vet. Parasitol. 105:191206
Odiere, M. R., M. E. Scott, H. A. Weiler, and K. G. Koski. 2010 Protein deficiency and nematode infection during pregnancy and lactation reduce maternal bone mineralization and neonatal linear growth in mice. J. Nutr. 140:1638-1645.

Ortega, H. H., N. R. Salvetti, and V. Padmanabhan. 2009. Developmental programming: Prenatal androgen excess disrupts ovarian steroid receptor balance . Reproduction 137:865-877.

Perri, A. F., M. E. Mejia, N. Licoff, S. Diab, N. Formia, A. Ornstein, D. Becu-Villalobos, and I. M. Lacau-Mengido. 2013. Gastrointestinal parasite control during prepuberty improves mammary parenchyma development in Holstein heifers. Vet. Parasitol. 198:345-350.

Perri, A. F., M. E. Mejia, N. Licoff, L. Lazaro, M. Miglierina, A. Ornstein, D. Becu-Villalobos, and I. M. Lacau-Mengido. 2011. Gastrointestinal parasites presence during the peripartum decreases total milk production in grazing dairy Holstein cows. Vet. Parasitol. 178:311-318.

Plath-Gabler, A., C. Gabler, F. Sinowatz, B. Berisha, and D. Schams. 2001. The expression of the IGF family and GH receptor in the bovine mammary gland. J. Endocrinol. 168:39-48.

Reindl, K. M., and M. A. Sheridan. 2012. Peripheral regulation of the growth hormone-insulin-like growth factor system in fish and other vertebrates. Comp. Biochem. Physiol. A Mol. Integr. Physiol. 163:231-245.

Sejrsen, K., and S. Purup. 1997. Influence of prepubertal feeding level on milk yield potential of dairy heifers: A review. J. Anim. Sci 75:828-835.

Sejrsen, K., S. Purup, M. Vestergaard, and J. Foldager. 2000. High body weight gain and reduced bovine mammary growth: Physiological basis and implications for milk yield potential. Domest. Anim. Endocrinol. 19:93-104.

Sithole, F., I. Dohoo, K. Leslie, L. DesCoteaux, S. Godden, J. Campbell, H. Stryhn, and J. Sanchez. 2005. Effect of eprinomectin treatment at calving on milk production in dairy herds with limited outdoor exposure. J. Dairy Sci. 88:929-937.

Symons, L. E. 1985. Anorexia: Occurrence, pathophysiology, and possible causes in parasitic infections. Adv. Parasitol. 24:103-133.

Tapanainen, P. J., P. Bang, K. Wilson, T. G. Unterman, H. J. Vreman, and R. G. Rosenfeld. 1994. Maternal hypoxia as a model for intrauterine growth retardation: Effects on insulin-like growth factors and their binding proteins. Pediatr. Res. 36:152-158.

Tolleson, D. R., G. E. Carstens, T. H. Welsh Jr., P. D. Teel, O. F Strey, M. T. Longnecker, S. D. Prince, and K. K. Banik. 2012. Plane of nutrition by tick-burden interaction in cattle: Effect on growth and metabolism. J. Anim. Sci. 90:3442-3450.

Tolleson, D. R., P. D. Teel, J. W. Stuth, O. F. Strey, T. H. Welsh Jr. G. E. Carstens, M. T. Longnecker, K. K. Banik, and S. D. Prince. 2010. Effects of a lone star tick (Amblyomma americanum) burden on performance and metabolic indicators in growing beef steers. Vet. Parasitol. 173:99-106.

Tucker, H. A. 1987. Quantitative estimates of mammary growth during various physiological states: A review. J. Dairy Sci. 70:1958-1966.

Weber, M. S., S. Purup, M. Vestergaard, R. M. Akers, and K. Sejrsen 2000. Regulation of local synthesis of insulin-like growth factor-I and binding proteins in mammary tissue. J. Dairy Sci. 83:30-37.

Whitlock, B. K., M. J. VandeHaar, L. F. Silva, and H. A. Tucker 2002. Effect of dietary protein on prepubertal mammary development in rapidly growing dairy heifers. J. Dairy Sci. 85:1516-1525.

Wolf, E., P. M. Jehle, M. M. Weber, H. Sauerwein, A. Daxenberger, B. H. Breier, U. Besenfelder, L. Frenyo, and G. Brem. 1997. Human insulin-like growth factor I (IGF-I) produced in the mammary glands of transgenic rabbits: Yield, receptor binding, mitogenic activity, and effects on IGF-binding proteins. Endocrinology 138:307-313.

Wolf, E., H. Lahm, M. Wu, R. Wanke, and A. Hoeflich. 2000. Effects of IGFBP-2 overexpression in vitro and in vivo. Pediatr. Nephrol. $14: 572-578$.

Woodward, T. L., J. W. Xie, and S. Z. Haslam. 1998. The role of mammary stroma in modulating the proliferative response to ovarian hormones in the normal mammary gland. J. Mammary Gland Biol. Neoplasia 3:117-131. 